\title{
A comparison of iron absorption in adults and infants consuming identical infant formulas
}

\author{
Richard F. Hurrell ${ }^{1} \dagger$, Lena Davidsson ${ }^{1}$, Manju Reddy ${ }^{2 *}$, Peter Kastenmayer ${ }^{3}$ \\ and James D. Cook ${ }^{2}$ \\ ${ }^{1}$ Laboratory for Human Nutrition, Swiss Federal Institute of Technology Zürich, PO Box 474, \\ CH-8803 Rüschlikon, Switzerland \\ ${ }^{2}$ Kansas University Medical Center, Kansas City, KS 66103, USA \\ ${ }^{3}$ Nestlé Research Centre, PO Box 44, CH-1000 Lausanne 26, Switzerland
}

(Received 5 December 1996 - Revised 9 June 1997 - Accepted 30 June 1997)

\begin{abstract}
Fe absorption was estimated in adults and infants from the erythrocyte incorporation of $\mathrm{Fe}$ isotopes added to infant formula. Fe absorption was measured in adults using radioisotopes, and in infants with a stable-isotope technique. In adults, the geometric mean Fe absorption from a ready-to-feed soya formula with its native phytic acid content was $2.4 \%$. This increased to $6.0 \%(P<0.05)$ after almost complete dephytinization. In infants, mean Fe absorption values were 3.9 and $8.7 \%$ respectively from the same products $(P<0.05)$. In adults, mean $\mathrm{Fe}$ absorption from a spray-dried soya formula containing $110 \mathrm{mg}$ ascorbic acid/l was $4.1 \%$, increasing to $5.3 \%(P<0.05)$ when ascorbic acid was doubled to $220 \mathrm{mg} / \mathrm{l}$. In infants, mean $\mathrm{Fe}$ absorption values were 5.7 and $9.5 \%(P<0.05)$ from the same products. Mean Fe absorption from a milk-based formula was $6.5 \%$ in adults compared with $6.7 \%$ in infants. All meals in the adult and infant studies were fed using an identical meal size of $217 \mathrm{~g}$. Increasing the meal size threefold in adults did not change fractional $\mathrm{Fe}$ absorption. Mean $\mathrm{Fe}$ absorption values for each meal were lower in adults than in infants, but the relative inhibitory effect of phytic acid and the enhancing effect of ascorbic acid were similar. We conclude that Fe absorption studies in adults can be used to assess the influence of enhancers and inhibitors of Fe absorption in infant formulas fed to infants. Further studies, however, are required to extend these findings to weaning foods and complete meals.
\end{abstract}

Iron: Formula intake: Infants: Phytate: Ascorbic acid

Most information on the food components which influence the absorption of dietary $\mathrm{Fe}$ in man has been obtained using the extrinsic tag double radio-Fe technique in adult human subjects consuming single meals labelled with ${ }^{55} \mathrm{Fe}$ or ${ }^{59} \mathrm{Fe}$ (Cook et al. 1972; Hallberg \& Bjorn-Rasmussen, 1972). These studies have demonstrated that the food components most inhibitory to Fe absorption are phytic acid (Hallberg et al. 1987; Hurrell et al. 1992), polyphenols (Disler et al. 1975; Gillooly et al. 1983), Ca (Hallberg et al. 1991) and legume proteins (Lynch et al. 1994). The major food components which enhance $\mathrm{Fe}$ absorption are muscle tissue (Layrisse et al. 1984), ascorbic acid (Cook \& Monsen, 1977; Ballot et al. 1987) and perhaps other organic acids (Gillooly et al. 1983). Although single meal studies may exaggerate the influence of specific food components in highly-varied adult diets (Cook et al. 1991), they are potentially more important for predicting $\mathrm{Fe}$ absorption from infant diets which often consist of only a small number of food items.

Infancy is a critical period for $\mathrm{Fe}$ nutrition and, even in industrialized countries, many infants develop $\mathrm{Fe}$ deficiency anaemia (DeMaeyer \& Adiels-Tegman, 1985) due mainly to an inadequate supply of absorbable $\mathrm{Fe}$. This condition can delay, perhaps irreversibly, their mental and psychomotor development (Lozoff et al. 1991). From about 4 months of age, human milk and the babies' Fe stores are no longer sufficient to provide enough $\mathrm{Fe}$ for the rapidly expanding blood volume (Dallman et al. 1980). This extra

* Present address: Iowa State University, Ames, IA 50011, USA.

† Corresponding author: Dr Richard F. Hurrell, fax +41-1-724 01 83, email richard.hurrell@ilw.agri.ethz.ch 
Fe requirement must come from other food sources and is often obtained from commercial products such as infant formulas, infant cereals and, at a later date, home-prepared or industrially-prepared meals based on vegetables, meats and fruits. When formulating commercial infant food products, the manufacturer needs to ensure adequate $\mathrm{Fe}$ nutrition and thus needs to know the influence of different food components on $\mathrm{Fe}$ absorption. As radioisotopic studies in infants are unacceptable for ethical reasons, results from adult Fe absorption studies have been used, assuming that $\mathrm{Fe}$ absorption in the adult is a good model for $\mathrm{Fe}$ absorption in infants.

Recently a double stable-isotope methodology has been developed (Kastenmayer et al. 1994) which permits the measurement of Fe absorption in infants. This method has a very similar protocol to the radio-Fe studies in that two different test meals labelled with either ${ }^{57} \mathrm{Fe}$ or ${ }^{58} \mathrm{Fe}$ are fed on consecutive days and absorption is quantified based on the incorporation of the isotope into circulating erythrocytes $14 \mathrm{~d}$ after administration. In the present study, we compared $\mathrm{Fe}$ absorption in both adults and infants from soya-based and milk-based infant formulas by measuring the erythrocyte incorporation of $\mathrm{Fe}$ isotopes. In soya formulas, we further compared the relative enhancing effect of ascorbic acid, the inhibitory effect of phytic acid and the influence of adult meal size. Fe absorption was measured in adults using radioisotopes, and in infants using stable-isotopes. The infant studies have been previously published (Davidsson et al. 1994; Kastenmayer et al. 1994).

\section{Materials and methods}

\section{Iron absorption studies in adults}

Two Fe absorption studies were made in two groups of nine human subjects. The ages of the volunteers (ten male, eight female) ranged from 21 to 34 years. All were in good health and denied a history of disorders known to influence $\mathrm{Fe}$ absorption. Serum ferritin determinations ranged from 6 to $285 \mu \mathrm{g} / 1$ indicating a wide range of Fe stores. Three subjects (two female, one male) were $\mathrm{Fe}$ deficient as defined by a serum ferritin concentration $\leq 12 \mu \mathrm{g} / 1$. Written informed consent was obtained from each volunteer before beginning the investigation and all experimental procedures were approved by the Human Subject Committee at the University of Kansas Medical Center.

In study 1 , the volunteers were given three test meals. Meal A was a liquid 'ready-to-feed' soya infant formula containing its native phytic acid content, meal $B$ was the same soya formula which had been enzymically dephytinized, and meal $C$ was a spray-dried milk-based infant formula diluted in water before feeding. All meals were given as a relatively small infant portion size $(217 \mathrm{~g})$. In study 2 , the volunteers were given four test meals, all based on a spray-dried soya infant formula which was diluted in water before use. Meal D was the formula containing its normal ascorbic acid level $(110 \mathrm{mg} / \mathrm{l})$ and meal $\mathrm{E}$ was the formula with double the normal ascorbic acid level $(220 \mathrm{mg} / \mathrm{l})$. Both meals were given as the smaller infant portion size ( $217 \mathrm{~g}$ ). Meals $\mathrm{F}$ and $\mathrm{G}$ similarly contained the soya formula with normal and double ascorbic acid levels but were given in three times larger adult portion sizes (651 g).

The Fe absorption measurements were made using double radio-Fe tracers administered sequentially. All meals were administered between 07.00 and 09.00 hours after an overnight fast and nothing but water was allowed for a further $3 \mathrm{~h}$. The test meals were labelled by the extrinsic tag method as previously described by adding either $37 \mathrm{kBq}{ }^{59} \mathrm{FeCl}_{3}$ or $111 \mathrm{kBq}^{55} \mathrm{FeCl}_{3}$ to a $1 \mathrm{ml}$ solution containing $0.1 \mathrm{mg} \mathrm{Fe}$ as $\mathrm{FeCl}_{3}$ in $0.01 \mathrm{M}-\mathrm{HCl}$ (Cook et al. 1972).

On the day preceding administration of the first test meal, $30 \mathrm{ml}$ blood was obtained from each subject for measurement of packed cell volume, serum ferritin (Flowers et al. 1986), and background radioactivity. The first and second test meals (meals A and B in study 1 , meals $\mathrm{D}$ and $\mathrm{E}$ in study 2), labelled with ${ }^{59} \mathrm{Fe}$ and ${ }^{55} \mathrm{Fe}$ respectively, were given on days 2 and 3 of the study, and again on days 4 and 5 . Half the subjects received the meals in the order ABAB (DEDE), the other half received the meals in the order BABA (EDED). At $14 \mathrm{~d}$ after the last administration (day 16), $30 \mathrm{ml}$ blood was drawn for measurement of incorporated erythrocyte radioactivity. Third and fourth (in study 2 only) test meals (meal $C$ in study 1 , meals $F$ and $G$ in study 2) tagged with separate radio-Fe labels were similarly given on days $16,17,18$ and 19 , and a final blood sample was obtained on day 31 to determine the increase in erythrocyte radioactivity. Measurements of blood radioactivity were performed on duplicate $10 \mathrm{ml}$ samples of whole blood by a modification of the method of Eakins \& Brown (1966). Percentage absorption was calculated on the basis of the blood volume estimated from height and weight (Wennesland et al. 1959; Brown et al. 1962) and an assumed erythrocyte incorporation for absorbed radioactivity of $80 \%$ (Hosein et al. 1967).

\section{Iron absorption studies in infants}

The infant $\mathrm{Fe}$ absorption studies have already been published (Davidsson et al. 1994; Kastenmayer et al. 1994). Three studies were made in a total of nineteen infants (mean age 20 weeks) according to a double stableisotope technique in which each infant received two meals labelled with either ${ }^{57} \mathrm{Fe}$ or ${ }^{58} \mathrm{Fe}$. Details of the subjects and the methodology are given in the earlier publications. The incorporation of stable $\mathrm{Fe}$ isotope into the circulating haemoglobin was quantified using thermal ionization mass spectrometry.

In the first study (Kastenmayer et al. 1994), Fe absorption was measured from the cows' milk-based infant formula (meal G). In the second study (Davidsson et al. 1994), Fe absorption from the ready-to-feed soya infant formula was compared before and after dephytinization (meals A and B). In the third study (Davidsson et al. 1994), Fe absorption was measured from the spray-dried soya formula, mixed with water before feeding, and containing either normal $(110 \mathrm{mg} / \mathrm{l})$ or double normal $(220 \mathrm{mg} / \mathrm{l})$ ascorbic acid concentrations (meals $\mathrm{C}$ and $\mathrm{D}$ ). 


\section{Test meals}

The compositions of the cows' milk-based formula and the soya-based infant formula are shown in Table 1 and the meal composition is given in Table 2. The milk-based formula was a commercial whey-adapted formula (PreBeba, Nestlé, Frankfurt, Germany) which was manufactured without added $\mathrm{Fe}$. $\mathrm{Fe}$ was added as $\mathrm{FeSO}_{4}$ at the time of feeding. The 'ready-to-feed' formulas were manufactured specifically for the study at Alpura Koreco (Konolfingen, Switzerland) according to the specifications of a commercial product (Nestlé SA, Vevey, Switzerland) but without the addition of $\mathrm{Fe}, \mathrm{Zn}$ or ascorbic acid, which were added to the meal at the time of feeding. Soyabean protein isolate (Supro 1611, Protein Technologies International, St Louis, MO, USA) was the sole protein source. One formula was manufactured containing the native phytic acid content of the soya isolate, and a second was produced in which the phytic acid was almost completely degraded by the addition of phytase (EC 3.1.3.8). The enzyme (Finase S40), purchased from Alko Ltd, Helsinki, Finland was derived from Aspergillus niger and contained 40 phytase units/l. The formulas were aseptically filled into cans. The second soya formula was formulated and manufactured in a similar way to the first except that a different protein source was used (Edipro A, Protein Technologies International), the product was not dephytinized, and it was spray-dried and packed into cans under $\mathrm{N}_{2}$.

\section{Analytical techniques}

The contents of $\mathrm{Fe}$ and $\mathrm{Ca}$ in the formulas were analysed by atomic absorption spectrometry as described previously (Davidsson et al. 1994). N was analysed by the Kjeldahl technique and protein was calculated by applying a factor of 6.25 to the $\mathrm{N}$ values. Phytic acid was measured by cerium sulfate precipitation according to a modification of the method of Makover (1970). Ascorbic acid was measured by electrometric titration with 2,6-dichlorophenol indophenol (Harris et al. 1992).

\section{Statistical analysis}

Percentage absorption values were converted to logarithms before statistical analysis and results reconverted to antilogarithms to recover the original units (Cook et al. 1969). In the adult studies, paired $t$ tests were used to compare absorption values from test meals within each study by determining whether the mean log absorption ratios differed significantly from unity.

\section{Results}

The results of the human $\mathrm{Fe}$ absorption studies are shown in Table 3. In study 1, geometric mean Fe absorption from the ready-to-feed soya formula with its native phytate content was $2.4 \%$. This increased significantly to $6.0 \%(P<0.05)$ after the product had been almost completely dephytinized.

Table 1. Protein, iron, calcium, phytic acid and ascorbic acid content per litre of infant formula as fed

\begin{tabular}{|c|c|c|c|c|c|}
\hline & $\begin{array}{l}\text { Protein } \\
(g / l)\end{array}$ & $\begin{array}{c}\mathrm{Fe} \\
(\mu \mathrm{mol} / \mathrm{l})\end{array}$ & $\underset{(\mathrm{mmol} /)}{\mathrm{Ca}}$ & $\begin{array}{c}\text { Phytic acid } \\
(\mu \mathrm{mol} / /)\end{array}$ & $\begin{array}{c}\text { Absorbic acid } \\
(\mu \mathrm{mol} / /)\end{array}$ \\
\hline Cows' milk formula & 17.3 & 213 & 13.6 & - & 454 \\
\hline $\begin{array}{l}\text { Ready-to-feed soya formula: } \\
\text { native phytic acid } \\
\text { dephytinized }\end{array}$ & $\begin{array}{l}20.4 \\
18.4\end{array}$ & $\begin{array}{l}295 \\
300\end{array}$ & $\begin{array}{l}10.8 \\
10.7\end{array}$ & $\begin{array}{l}611 \\
<2\end{array}$ & $\begin{array}{l}624 \\
624\end{array}$ \\
\hline $\begin{array}{l}\text { Spray-dried soya formula: } \\
\text { normal ascorbic acid } \\
\text { double ascorbic acid }\end{array}$ & $\begin{array}{l}19.4 \\
19.4\end{array}$ & $\begin{array}{l}300 \\
300\end{array}$ & $\begin{array}{l}10.9 \\
10.9\end{array}$ & $\begin{array}{l}615 \\
615\end{array}$ & $\begin{array}{r}624 \\
1249\end{array}$ \\
\hline
\end{tabular}

Table 2. Meal composition*

\begin{tabular}{|c|c|c|c|c|}
\hline \multirow[b]{2}{*}{ Meal } & \multirow[b]{2}{*}{ Formula (g) } & \multirow{2}{*}{$\begin{array}{c}\text { Deionized } \\
\text { distilled } \\
\text { water }(g)\end{array}$} & \multicolumn{2}{|c|}{ Additions $\uparrow$} \\
\hline & & & $\mathrm{Zn \ddagger}$ (mg) & Ascorbic acid $\S(\mathrm{mg})$ \\
\hline $\begin{array}{l}\text { A Ready-to-feed soya formula (native phytate) } \\
\text { B Ready-to-feed soya formula (dephytinized) } \\
\text { C Spray-dried soya milk formula } \\
\text { D Spray-dried soya formula (normal ascorbic acid) } \\
\text { E Spray-dried soya formula (double ascorbic acid) } \\
\text { F Spray-dried soya formula (normal ascorbic acid) } \\
\text { G Spray-dried soya formula (double ascorbic acid) }\end{array}$ & $\begin{array}{r}217 \\
217 \\
28 \\
28 \\
28 \\
84 \\
84\end{array}$ & $\begin{array}{r}- \\
\overline{189} \\
189 \\
189 \\
567 \\
567\end{array}$ & $\begin{array}{l}1.08 \\
1.08 \\
- \\
1.2 \\
1.2 \\
3.75 \\
3.75\end{array}$ & $\begin{array}{r}23 \\
23 \\
- \\
23 \\
46 \\
69 \\
138\end{array}$ \\
\hline
\end{tabular}

- For further information on formulas see pp. 32-33. Formulas A, B, D-G were prepared especially for the study, according to commercial specifications, but without the addition of $\mathrm{Fe}, \mathrm{Zn}$ and ascorbic acid; formula $\mathrm{C}$ was a commercial formula.

† $\mathrm{FeSO}_{4}$ was added to meals A-E.to adjust the total $\mathrm{Fe}$ content to $2.5 \mathrm{mg} / \mathrm{meal}$ and to meals $\mathrm{F}$ and $\mathrm{G}$ to adjust the total Fe content to $7.5 \mathrm{mg} / \mathrm{meal}$. The radioactive or stable isotopes were included in the $\mathrm{FeSO}_{4}$ addition.

$\ddagger \mathrm{As} \mathrm{ZnSO}_{4}$ (Merck, Darmstadt, Germany).

$\S$ Merck, Darmstadt, Germany. 
Table 3. Iron absorption from infant formulas in adults

\begin{tabular}{|c|c|c|c|c|c|}
\hline $\begin{array}{l}\text { Study, number of subjects } \\
\text { and mean age }\end{array}$ & $\begin{array}{l}\text { Packed cell } \\
\text { volume (\%) }\end{array}$ & $\begin{array}{l}\text { Serum ferritin* } \\
\qquad(\mu \mathrm{g} / \mathrm{l})\end{array}$ & Meals & $\begin{array}{l}\text { Meal size } \\
\quad(g)\end{array}$ & $\begin{array}{l}\text { Iron absorption* } \\
\text { (\% of dose) }\end{array}$ \\
\hline 1. (n 5M, 4F, 24 years) & 45 & $36(23-57)$ & $\begin{array}{l}\text { A. Soya formula (ready-to-feed), native phytate } \\
\text { B. Soya formula (ready-to-feed), dephytinized } \\
\text { C. Milk formula }\end{array}$ & $\begin{array}{l}217 \\
217 \\
217\end{array}$ & $\begin{array}{ll}2.4^{\mathrm{a}} & (1.7-3.4) \\
6.0^{\mathrm{b}} & (4.5-8.0) \\
6.5^{\mathrm{b}} & (4.7-9.0)\end{array}$ \\
\hline 2. ( $n 5 \mathrm{M}, 4 \mathrm{~F}, 25$ years) & 44 & $33(26-42)$ & $\begin{array}{l}\text { D. Soya formula (spray-dried), normal ascorbic acid } \\
\text { E. Soya formula (spray-dried), double ascorbic acid } \\
\text { F. Soya formula (spray-dried), normal ascorbic acid } \\
\text { G. Soya formula (spray-dried), double ascorbic acid }\end{array}$ & $\begin{array}{l}217 \\
217 \\
651 \\
651\end{array}$ & $\begin{array}{l}4.1^{\mathrm{a}}(3 \cdot 2-5 \cdot 2) \\
5 \cdot 3^{\mathrm{b}}(4 \cdot 2-6 \cdot 8) \\
4 \cdot 3^{\mathrm{ab}}(3 \cdot 6-5 \cdot 3) \\
7.0^{\mathrm{bc}}(5 \cdot 5-8 \cdot 9)\end{array}$ \\
\hline
\end{tabular}

a,b,c Within study 1 (meals $A-C$ ), and within study 2 (meals $D-G$ ), mean values not sharing a common superscript letter were significantly different $(P<0.05$ ).

* Geometric mean values with the variance $( \pm 1 \mathrm{SE})$ in parentheses.

Table 4. Iron absorption in adults and infants* consuming the same infant formulas

\begin{tabular}{|c|c|c|c|c|c|}
\hline \multirow[b]{2}{*}{ Meals, meal size } & \multicolumn{2}{|c|}{$\begin{array}{c}\text { Iron absorption } \dagger \\
(\%)\end{array}$} & \multirow[b]{2}{*}{ Ratio } & \multicolumn{2}{|c|}{ Absorption ratio } \\
\hline & Adult & Infant & & Adult & Infant \\
\hline $\begin{array}{l}\text { A Soya formula (ready-to-feed) } \\
\text { native phytate, } 217 \mathrm{~g}\end{array}$ & 2.4 & 3.9 & $B: A$ & 2.49 & 2.23 \\
\hline $\begin{array}{l}\text { B Soya formula (ready-to-feed) } \\
\text { dephytinized, } 217 \mathrm{~g}\end{array}$ & 6.0 & 8.7 & & & \\
\hline $\begin{array}{l}\text { C Soya formula (spray-dried) } \\
\text { normal ascorbic acid, } 217 \mathrm{~g}\end{array}$ & $4 \cdot 1$ & $5 \cdot 7$ & $\mathrm{D}: \mathrm{C}$ & $1 \cdot 31$ & 1.67 \\
\hline $\begin{array}{l}\text { D Soya formula (spray-dried) } \\
\text { double ascorbic acid, } 217 \mathrm{~g}\end{array}$ & $5 \cdot 3$ & $9 \cdot 5$ & & & \\
\hline $\begin{array}{l}\text { E Soya formula (spray-dried) } \\
\text { normal ascorbic acid, } 651 \mathrm{~g}\end{array}$ & $4 \cdot 3$ & - & $F: E$ & 1.61 & - \\
\hline $\begin{array}{l}\text { F Soya formula (spray-dried) } \\
\text { double ascorbic acid, } 651 \mathrm{~g}\end{array}$ & $7 \cdot 0$ & - & & & \\
\hline G Milk formula, $217 \mathrm{~g}$ & 6.5 & 6.7 & & & \\
\hline
\end{tabular}

* Values for Fe absorption in infants have been reported earlier (Davidsson et al. 1994; Kastenmayer et al. 1994).

$\uparrow$ Geometric means.

Mean Fe absorption from the dephytinized soya formula $(6.0 \%)$ was not significantly different from that from the whey-adapted milk-based formula $(6.5 \%, P>0.2)$. In study 2 , mean absorption from the spray-dried formula was $4.1 \%$ when it contained its regular ascorbic acid level $(110 \mathrm{mg} / \mathrm{l})$ and increased to $5.3 \%$ when the concentration of ascorbic acid was doubled. When the same spray-dried formulas were fed at a three times greater quantity, mean Fe absorption was $4.3 \%$ at the regular ascorbic acid level and $7.0 \%$ at double the ascorbic acid.

Fe absorption in adults is compared with that obtained in infants fed with the same meals in Table 4. Percentage geometric mean $\mathrm{Fe}$ absorption values were similar between adult and infant. The mean adult values ranged from 2.4 to $7.0 \%$ whereas the infant values were slightly higher ranging from 3.9 to $9.5 \%$. Mean serum ferritin values were higher in the adult studies $(36 \mu \mathrm{g} / \mathrm{l}, 33 \mu \mathrm{g} / \mathrm{l}$; Table 3$)$ than those previously reported for the infant studies; $15.6 \mu \mathrm{g} / \mathrm{l}$ in the milk formula study (Kastenmayer et al. 1994), $3.5 \mu \mathrm{g} / \mathrm{l}$ in the ready-to-feed formula study and $29.3 \mu \mathrm{g} / \mathrm{l}$ in the spray-dried soya formula study (Davidsson et al. 1994).

The relative enhancing effects of dephytinization and ascorbic acid addition were also similar in both adults and infants. Dephytinization of the ready-to-feed soya formula increased Fe absorption 2.49-fold in adults and 2.23-fold in infants (Table 4), when both groups were given the same small infant meal size. Doubling the ascorbic acid level of the spray-dried soya formula increased Fe absorption 1.67fold in infants compared with 1.31-fold in adults when given the infant meal size and 1.61-fold with an adult meal size.

\section{Discussion}

This is the first study to compare directly $\mathrm{Fe}$ absorption from adults and infants given identical test meals administered under similar conditions. The results, although from a relatively small number of observations, would indicate that adult $\mathrm{Fe}$ absorption measurements can usefully predict the relative enhancing and inhibitory effects that different food components would have on $\mathrm{Fe}$ absorption in infants. It should be stressed, however, that we have investigated only one inhibitor of $\mathrm{Fe}$ absorption (phytic acid) and one enhancer (ascorbic acid) and that similar studies would be needed to confirm the relative effects of phenolic compounds, $\mathrm{Ca}$, vegetable proteins and muscle tissue in adults and infants. In addition, our findings were with liquid test meals consisting of $\mathrm{Fe}$-fortified infant formulas and it is not known whether they can be extended to semi-solid meals such as weaning cereals and infant meals containing vegetables and meat. Nevertheless, the present results indicate that $\mathrm{Fe}$ absorption studies in adults or infants would give the infant formula manufacturer the same message: that fractional $\mathrm{Fe}$ absorption from soya 
formula can be increased to a similar level as that obtained from milk-based formula by either removing phytic acid or by adding ascorbic acid.

The mean percentage $\mathrm{Fe}$ absorption values from the formulas were also similar in adults and infants ranging from about 2 to $10 \%$ (Table 4 ). In both adults and infants, absorption was lowest from the ready-to-feed soya formula with native phytate and highest from the spray-dried soya formula with double ascorbic acid content. Mean Fe absorption in adults from the five meals tested was 2 $45 \%$ (mean $29 \%$ ) lower than in infants. This could, in part, be due to differences in $\mathrm{Fe}$ status, differences in erythrocyte incorporation or differences in gut physiology. In relation to erythrocyte incorporation, it is customary to estimate $80 \%$ incorporation of the newly absorbed $\mathrm{Fe}$ into erythrocytes in adults (Hosein et al. 1967) compared with $90 \%$ in infants. The latter value was used in our previous infant studies (Davidsson et al. 1994; Kastenmayer et al. 1994). In relation to $\mathrm{Fe}$ status, if the mean serum ferritin value of $34.5 \mu \mathrm{g} / 1$ measured in the adults in our study was decreased to $16.5 \mu \mathrm{g} /$, the mean serum ferritin value measured in the infants, then $\mathrm{Fe}$ absorption in the adults would more than double (Cook et al. 1991). However, although studies in adults have shown a reciprocal log-log relationship between $\mathrm{Fe}$ absorption and serum ferritin with a slope of 1.0 (Cook et al. 1991), there are inconsistent reports on the relationship between $\mathrm{Fe}$ stores and $\mathrm{Fe}$ absorption in infants (Fomon et al. 1988; Davidsson et al. 1994).

The influence of meal size was investigated in study 2 since it was hypothesized that a better comparison of $\mathrm{Fe}$ absorption between infants and adults could be obtained if infants were given an infant meal size and adults were given a larger adult meal size. We therefore increased the adult meal size threefold (Table 3; study 2, meals F, G). Meal size could theoretically alter the absolute fractional absorption and perhaps also the relative enhancing and inhibitory effects. Increasing the meal size, however, had little influence on mean Fe absorption from the spray-dried soya formula with normal ascorbic acid (4.1 v. $4.3 \%$, meals $\mathrm{D}$ and F, Table 3) $(P=0.76)$. In other studies in adults, we have also demonstrated that meal size has no significant effect on Fe absorption. (JD Cook, MA Reddy, and RF Hurrell, unpublished results). Similarly there was little or no influence of meal size on the enhancing and inhibitory effects of meal components. When the smaller meal size was given to both adults and infants, the inhibitory effect of phytic acid was almost identical. Dephytinization of the soya formula increased Fe absorption 2.49 -fold in the adult studies and 2.23-fold in the infant studies (Table 4 ). The enhancing effect of added ascorbic acid in adult meals was closer to that in infant meals (1.67-fold increase) when the larger meal size was fed (1.61-fold increase) than with the smaller meal size (1.31-fold increase, Table 4$)$, however, the latter ratios were not statistically different $(P=0 \cdot 17)$.

In conclusion, these studies indicate that the food manufacturer can use results from Fe absorption studies in adults to assess the influence of enhancers and inhibitors of $\mathrm{Fe}$ absorption in infant formulas fed to infants. Further studies are required to extend these findings to other infant foods and to the other food components which influence $\mathrm{Fe}$ absorption.

\section{References}

Ballot D, Baynes RD, Bothwell TH, Gillooly M, Macfarlane BJ, McPhail AP, Lyons G, Derman GP, Bezwoda WR, Torrance JD \& Bothwell JE (1987) The effects of fruit juices and fruits on the absorption of iron from a rice meal. British Journal of Nutrition 57, 331-343.

Brown E, Hopper J Jr, Hodges JL Jr, Bradley B, Wennesland R \& Yamauchi H (1962) Red cell, plasma, and blood volume in healthy women measured by radiochromium cell-labelling and hematocrit. Journal of Clinical Investigation 41, 21882190.

Cook JD, Dassenko SA \& Lynch SR (1991) Assessment of the role of non-heme iron availability in iron balance. American Journal of Clinical Nutrition 54, 717-722.

Cook JD, Layrisse M \& Finch CA (1969) The measurement of iron absorption. Blood 33, 421-429.

Cook JD, Layrisse M, Martinez-Torres C, Monsen E \& Finch CA (1972) Food iron absorption measured by an extrinsic tag. Journal of Clinical Investigation 51, 805-815.

Cook JD \& Monsen ER (1977) Vitamin C, the common cold, and iron absorption. American Journal of Clinical Nutrition $\mathbf{3 0}$, $235-241$.

Dallman PR, Siimes MA \& Stekel A (1980) Iron deficiency in infancy and childhood. American Journal of Clinical Nutrition 33, 86-118.

Davidsson L, Galan P, Kastenmayer P, Cherouvrier F, Juillerat MA, Hercberg S \& Hurrell RF (1994) Iron absorption in infants: the influence of phytic acid and ascorbic acid in formulas based on soya isolate. Pediatric Research 36, 816822.

DeMaeyer E \& Adiels-Tegman M (1985) The prevalence of anaemia in the world. World Health Statistics Quarterly 38, 302-316.

Disler PB, Lynch SR, Charlton RW, Torrance JD, Bothwell TH, Walker RB \& Mayet F (1975) The effect of tea on iron absorption. Gut 16, 193-200.

Eakins JD \& Brown DA (1966) An improved method for the simultaneous determination of iron-55 and iron-59 in blood by liquid scintillation counting. International Journal of Applied Radiation and Isotopes 17, 391-397.

Flowers CA, Kuizon M, Beard JL, Skikne BS, Covell AM \& Cook JD (1986) A serum ferritin assay for prevalence studies of iron deficiency. American Journal of Hematology 23, 141-151.

Fomon SJ, Janghorbani M, Ting BTG, Ziegler EE, Rogers RR, Nelson SE, Ostedgaard LS \& Edwards BB (1988) Erythrocyte incorporation of ingested 58 -iron by infants. Pediatric Research 24, $20-24$.

Gillooly M, Bothwell TH, Torrance JD, McPhail AP, Derman DP, Bezwoda WR, Mills W, Charlton RW \& Mayet F (1983) The effects of organic acids, phytates and polyphenols on iron absorption from vegetables. British Journal of Nutrition 49, 331-342.

Hallberg L \& Bjorn-Rasmussen E (1972) Determination of iron absorption from the whole diet. A new two-pool model using two radio-iron isotopes given as haem and non-haem iron. Scandinavian Journal of Haematology 9, 193-197.

Hallberg L, Brune M, Erlandsson M, Sandberg AS \& RossanderHulthen L (1991) Calcium: effect of different amounts on nonheme and heme-iron absorption in humans. American Journal of Clinical Nutrition 53, 112-119. 
Hallberg L, Rossander L \& Skanberg A-B (1987) Phytates and the inhibitory effect of bran on iron absorption in man. American Journal of Clinical Nutrition 45, 988-996.

Harris LJ, Mapson LW \& Wang YL (1992) Vitamin methods. A simple potentiometric method for determining ascorbic acid, suitable for use with coloured extracts. Biochemical Journal 36, 183-195.

Hosein F, Marsaglia G \& Finch CA (1967) Blood ferrokinetics in normal man. Journal of Clinical Investigation 46, 1-9.

Hurrell RF, Juillerat MA, Reddy MB, Lynch SR, Dassenko SA \& Cook JD (1992) Soya protein, phytate and iron absorption in man. American Journal of Clinical Nutrition 56, 573578.

Kastenmayer P, Davidsson L, Galan P, Cherouvrier F, Hercberg S \& Hurrell RF (1994) A double stable isotope technique for measuring iron absorption in infants. British Joumal of Nutrition 71, 411-424.

Layrisse M, Martinez-Torres C, Leets I, Taylor PG \& Ramirez J (1984) Effect of histidine, cysteine, glutathione or beef on iron absorption in humans. Journal of Nutrition 114, 217223.

Lozoff B, Jiminez E \& Abraham WW (1991) Long term development outcome of infants with iron deficiency. New England Journal of Medicine 325, 687-694.

Lynch SR, Dassenko SA, Cook JD, Juillerat MA \& Hurrell RF (1994) Inhibitory effect of soybean-protein-related moiety on iron absorption in humans. American Journal of Clinical Nutrition 60, 567-572.

Makover RU (1970) Extraction and determination of phytic acid in beans. Cereal Chemisty 47, 288-295.

Wennesland R, Brown E, Hopper J, Hodges JL, Guttentag OE, Scott KG, Tucker IN \& Bradley B (1959) Red cell, plasma and blood volume in healthy men measured by radiochromium $\left(\mathrm{Cr}^{51}\right)$ cell tagging and hematocrit: influence of age, somatotype and habits of physical activity on variance after regression of volumes to height and weight combined. Joumal of Clinical Investigation 38, 1065-1077. 